\title{
Brain Stem Glioma in Childhood: Acute Hemiplegic Onset
}

\author{
S.J. ROTHMAN and C.W. OLANOW
}

SUMMARY: Two children, age seven and 16 years, are described with the abrupt onset of a pure motor hemiplegia as the initial manifestation of a brain stem neoplasm. Subsequent rapid neurological deterioration localized the lesion to the brain stem and glioblastoma multiforme was diagnosed by surgical biopsy. It is suggested that brain stem gliomas with this unusual presentation are likely to be highly malignant and prone to rapid bulbar deterioration.

RESUMÉ: Nous décrivons le cas de deux enfants, âgés de 7 et 16 ans, qui eurent une hémiplégie motrice pure da début subit comme signe initial d'un tumeur du tronc cérébral. La détérioration neurologique rapide subséquente permit de localiser la lésion au tronc cérébral et un glioblastome multiforme fut diagnostiqué par biopsie. Nous proposons que les gliomes du tronc avec ce mode inhabituel de présentation, sont très malins et sujets à une détérioration bulbaire rapide.
From the Departments of Medicine (Neurology) and Pediatrics, Duke University Medical Center, North Carolina. .

Reprint requests to: S.J. Rothman, M.D. F.R.C.P (C), P.O. Box 3533, Duke University Medical Center, Durham. North Carolina, 27710.

Presented to the XVth Canadian Congress of Neuro Science, Ottawa, 1980.

\section{INTRODUCTION}

Brain stem gliomas have a peak age of onset between five and eight years (Matson, 1969). Cases have been described with onset up to age 60 years (Hara and Takeuchi, 1977). As a result of their critical anatomical location, these tumors generally have a poor prognosis. The a verage survival from onset of symptoms to death is 9 to 13.7 months and is related to the degree of malignancy of the tumor (Matson, 1969; Farwell, et al., 1977). Astrocytoma grades I and II have a mean survival of 18.1 months. Astrocytoma grades III and IV have a mean survival of 6.0 months (Farwell, et al., 1977). The interval from onset of symptoms to diagnosis is usually one to five months (Matson, 1969).

These tumors usually present with cranial nerve abnormalities and ataxia without signs of raised intracranial pressure. Personality changes may be one the major initial findings. Corticospinal tract abnormalities a re common and may be seen early in the clinical course but have not been described as the sole presenting feature in childhood. One case of a pure motor hemiplegia developing in a stroke-like fashion has been described as the presenting feature of a brain stem glioma in a 60 year-old woman (Levitt, et al., 1975). In this report we describe two children with brain stem gliomas in whom the initial symptom was sudden onset of a pure motor type of hemiplegia.

\section{CASE REPORTS}

The iwo cases are summarized in Table I.

Case I: A seven year-old boy, while wrestling with his brother, experienced the sudden onset of weakness in his right arm. By the following evening, the motor deficit had progressed to a right hemiplegia without facial involvement. Left carotid angiography did not demonstrate a significant lesion. Two days later the child was transferred to Duke University Medical
Center. On examination he had a moderately severe right spastic hemiplegia affecting the leg more than the arm and sparing the face. No other neurological abnormalities were detected. CT head scan, radioisotope brain scan, and EEG were all within normal limits. During two weeks in hospital the hemiplegia remained unchanged.

One week following discharge he was readmitted with the development of severe bulbar paralysis and ataxia. Endotracheal intubation was required. Repeat CT head scan demonstrated enlargement of the brain stem. Posterior fossa craniotomy did not demonstrate a significant extramedullary mass. Surgical biopsy of brain stem nodules revealed glioblastoma multiforme.

Post-operatively, the patient required permanent tracheostomy and gastrostomy. There was no response to radiation or steroid therapy. He continued to deteriorate and died nine months after presentation.

Case II: A 16 year-old girl developed the sudden onset of weakness in her right arm which rapidly progressed to involve her right leg. Five days later she complained of double vision and dysarthria and was admitted to a local hospital. During the subsequent ten days, she developed progressive bulbar weakness and required endotracheal intubation. CT head scan and CT metrizamide cisternography were normal.

She was transferred to Duke University Medical Center where a pneumoencephalogram demonstrated brain stem swelling. A posterior fossa exploration demonstrated no significant extramedullary mass. Surgical biopsy of the brain stem revealed

TABLE

\section{Clinical Evolution}

\section{PROBLEM}

CASE 1 CASE 11

$\begin{array}{lrr}\text { Hemiplegia } & \text { Day 0 } & \text { Day 0 } \\ \text { Hospitalization } & 2 & 5 \\ \text { Cranial neuropathy } & 17 & 5 \\ \text { Nasogastric tube feeding } & 23 & 15 \\ \text { Endotracheal intubation } & 23 & 16 \\ \text { Surgical biopsy } & 23 & 21 \\ \text { Tracheostomy } & 33 & 25 \\ \text { Gastrostomy } & 33 & 41\end{array}$

Death

Month 9 Month 13 
glioblastoma multiforme. Bulbar weakness progressed and she required tracheostomy and gastrostomy. Treatment with radiotherapy, steroids and BCNU failed to produce clinical improvement. She continued to progress and died 13 months after presentation.

\section{DISCUSSION}

Brain stem gliomas are a malignant disease by virtue of their location. Treatment with radiotherapy and chemotherapy rarely provides significant improvement. Correct diagnosis is necessary to properly institute supportive therapy and counsel the family regarding prognosis. We describe two children who presented with the sudden onset of a pure motor hemiplegia. In each case, the correct localization and diagnosis was only established after further clinical progression. Rapid deterioration necessitated endotracheal intubation prior to definitive tissue diagnosis. Biopsy revealed glioblastoma multiforme.
These cases illustrate several common features: (1) An acute stroke-like onset with a pure motor hemiplegia; (2) Rapid deterioration necessitating permanent respiratory support within 15 to 23 days from the onset of symptoms; (3) Glioblastoma multiforme of the brain stem.

These children are similar to the 60 year-old woman reported by Levitt who had the sudden onset of pure hemiplegia also due to glioblastoma multiforme of the brain stem (Levitt, et al., 1975). Acute stroke-like onset of an isolated hemiplegia is rare in brain stem gliomas and large series of cases make no mention of this presentation (Matson, 1969; Hara and Takeuchi, 1977; Farwell, et al., 1977; Masucci, et al., 1966; Dohrmann, et al., 1976; Gejerres, 1978). It is suggested that this presentation may result from sudden necrosis or infarction within a highly malignant neoplasm rather than merely reflecting a variation in the anatomical location of the tumor.

\section{REFERENCES}

DOHRMANN, G.J., FARWELL, J.R., FLANNERY, J.T. (1976). Glioblastoma multiforme in children. J. Neurosurg. 44, 442-448.

FARWELL, J.R., DOHRMANN, G.J., FLANNERY, J.T. (1977). Central nervous system tumors in children. Cancer, 40, 31233132.

GEJERRES, F., (1978). Clinical aspects and long-term prognosis of infratentorial intracranial tumours in infancy and childhood. Acta Neurol. Scandinav., 57, 3152.

HARA, M., TAKEUCHI, K., (1977). A temporal study of survival of patients with pontine gliomas. J. Neurol., 216, 189-196.

LEVITT, L.P., SELKOE, D.J., FRANKENFIELD, B., SCHOENE, W., (1975). Pure motor hemiplegia secondary to brain-stem tumour. J. Neurol. Neurosurg. and Psych. 38, 1240-1243.

MASUCCI, E.F., MERRERO, A.A., KURTZKE, J.F., FOX, J.L., (1966). Glioblastoma multiforme involving the posterior fossa. Diseases of the Nervous System, 27, 47-51.

MATSON, D.B., (1969). Tumors of the posterior fossa. In Neurosurgery of Infancy and Childhood. Springfield Illinois, Charles C. Thomas, pp. 410-479. 